ఠ

\title{
Nasal polyps in patients with asthma: prevalence, impact, and management challenges
}

This article was published in the following Dove Press journal:

Journal of Asthma and Allergy

14 March 2016

Number of times this article has been viewed

\section{Cristobal Langdon ${ }^{1,2}$ \\ Joaquim Mullol'-3}

'Rhinology Unit and Smell Clinic, Otorhinolaryngology Department, Hospital Clínic, ${ }^{2} \mathrm{Clinical}$ and Experimental Respiratory

Immunoallergy (IRCE), Institut d'Investigacions Biomèdiques August $\mathrm{Pi}$ i Sunyer (IDIBAPS), ${ }^{3}$ Centre for Biomedical Research in Respiratory Diseases (CIBERES), Barcelona, Catalonia, Spain
Correspondence: Joaquim Mullol Rhinology Unit and Smell Clinic, Department of Otorhinolaryngology, Hospital Clínic i Universitari, c/ Villarroel 170, Barcelona 08036, Catalonia, Spain

Tel + 34932279872

Fax +34932279813

Email jmullol@clinic.ub.es
Abstract: Patients with chronic rhinosinusitis with nasal polyps (CRSwNP) often have coexisting asthma under the concept of "United Airway Disease", being the combination of both diseases, which is one of the most challenging phenotypes to treat. Although clinicians have recognized this difficult-to-treat phenotype for many years, it remained poorly characterized. There is increasing epidemiological evidence linking chronic rhinosinusitis and asthma, but a good understanding of the pathophysiology and the combined management is still lacking. Bronchial asthma is more prevalent in patients who suffer chronic rhinosinusitis, while asthmatic patients have a greater prevalence of CRSwNP than patients without asthma. The effect of CRSwNP treatment, whether medical or surgical, in asthma is today less controversial after some studies have shown improvement of asthma after medical and/or surgical treatment of CRSwNP. However, direct comparisons between surgical and medical treatments are limited. Further randomized clinical trials are, however, still needed to better understand the management when both asthma and CRSwNP occur together. This review aims at summarizing the prevalence, impact, and management challenges regarding both asthma and CRSwNP.

Keywords: chronic rhinosinusitis, asthma, united airways, rhinosinusitis, corticosteroids, sinus surgery

\section{Introduction}

Chronic rhinosinusitis with nasal polyps (CRSwNP) is a chronic inflammatory disease of the upper airways. It is defined as the presence of two or more symptoms that persist for more than 12 weeks. Symptoms include facial pain/pressure, purulent nasal discharge, nasal obstruction, and decreased sense of smell during chronic inflammation and confirmed the presence of nasal polyps through endoscopy. ${ }^{1}$ On the other hand, asthma is a chronic inflammation of the lower airways involving episodic breathlessness and wheezing, with airway hyperresponsiveness to environmental stimuli, with a prevalence of $5 \%-10 \%$ in the general population. ${ }^{2}$ Asthmatic patients have a higher rhinosinusitis severity score than nonasthmatic patients, and more presence of nasal polyps regardless of atopic status, indicative of a strong relationship between CRSwNP severity and chronic airway inflammatory diseases. ${ }^{3}$

Since the introduction of the "United Airway Disease" concept, ${ }^{4}$ a large body of evidence from clinical epidemiology, pathophysiology, histology, and treatment outcomes has correlated asthma and CRSwNP. CRSwNP and asthma frequently coexist, ${ }^{1}$ both conditions sharing similar features of inflammation and remodeling. This association has been supported by numerous observations of similar histopathological changes ${ }^{5}$ and common inflammatory mediator infiltration. ${ }^{6}$ Typical histopathological 
findings of asthma, including airway remodeling (epithelial shedding and basement membrane thickening), eosinophilic infiltration, T-helper cell involvement, and IL-5 production are present in both asthma and CRSwNP, suggesting similar physiopathological processes. ${ }^{7,8}$

Although the argument for the existence of a link between upper and lower airway diseases is strong, the mechanism that underlies this connection remains under investigation. In this review, we will analyze the prevalence and the impact of management challenges regarding both asthma and CRSwNP.

\section{Epidemiology and prevalence}

CRSwNP is an inflammatory condition of the nose and paranasal sinuses of unknown cause, which is present in $2 \%-4 \%$ of the adult population. ${ }^{1,9} \mathrm{CRSwNP}$ is often associated with other respiratory diseases such as asthma, ${ }^{10}$ aspirin sensitivity, ${ }^{11,12}$ and idiopathic bronchiectasis. ${ }^{13}$ It has been reported that $20 \%-60 \%$ of patients with CRSwNP have asthma. ${ }^{14-16}$

The association between CRSwNP and asthma patients can be considered from two different perspectives: percentage of asthmatic patients developing CRSwNP and patients diagnosed with CRSwNP and with asthma. Bronchial asthma is more prevalent in patients suffering from CRS. ${ }^{1,9,17}$ On the other hand, patients with asthma have a greater prevalence of CRS than patients without asthma. ${ }^{18}$ Jarvis et $\mathrm{al}^{9}$ included over 52,000 adults, aged 18-75 years, recruited in 19 centers from 12 European countries. In all centers and at all ages, a strong association between asthma and CRS (adjusted OR: 3.47; 95\% CI: 3.20-3.76) was observed. The association with asthma was stronger in patients reporting both CRS and allergic rhinitis (adjusted OR: 11.85; 95\% CI: 10.57-13.17). Dixon et $\mathrm{al}^{19}$ included 2,031 asthmatic patients and demonstrated that the association with CRS was related to severe asthma, poorly controlled asthma, and asthma exacerbations, but not to decreased lung function. Interestingly, most patients with CRS without clinical asthma showed bronchial hyperresponsiveness when a methacholine challenge test was performed. Furthermore, up to $45 \%$ of CRSwNP patients have or will develop asthma. ${ }^{1,9,20}$ The prevalence of CRSwNP is higher in asthmatics (7\%) compared to the general population (4\%), ${ }^{21}$ and females present a greater proportion of CRSwNP in combination with asthma. ${ }^{19}$ In addition, Caucasian patients have shown a greater prevalence of CRSwNP and asthma than Asiatic patients, ${ }^{22,23}$ while the severity of CRS is higher when concomitant asthma exists. ${ }^{3,24-26}$ In nonatopic asthma and late-onset asthma, CRSwNP was found even more frequently, from $15 \%$ to $26 \%$ depending on the study, ${ }^{27,28}$ while more than $60 \%$ of CRSwNP patients have some level of lower airway involvement. ${ }^{29}$

Aspirin-exacerbated respiratory disease (AERD), a syndrome characterized by the presence of aspirin sensitivity/ intolerance, asthma, and CRSwNP, has an estimated prevalence of $1 \%$ in the general population and $10 \%-20 \%$ among asthmatics. ${ }^{1,12,30}$ During the natural evolution of the disease, a clinical history of rhinitis or CRS usually precedes asthma and the development of aspirin hypersensitivity. In the European Network on Aspirin-Induced Asthma cohort study, the disease followed a typical pattern: persistent rhinitis/ rhinosinusitis appeared first (mean age 30 years), being associated to a flulike infection in half of the patients. This was followed by asthma after 2 years (mean age 32 years), and aspirin-induced respiratory reactions and nasal polyposis after 4 years (mean age 34 years). ${ }^{11}$ The clinical presentation in the different European countries was remarkably similar. In women, who outnumbered men by a ratio of $2.3: 1$, the onset of symptoms occurred significantly earlier, and the disease was more severe than in men. Once developed, CRSwNP and asthma evolution is usually independent of the aspirin and nonsteroidal anti-inflammatory drug avoidance. ${ }^{31}$

The typical clinical picture of patients with CRSwNP and asthma has been characterized by older age, longer duration of nasal symptoms, higher incidence of allergic rhinitis, bronchial obstruction, higher computed tomography $(\mathrm{CT})$ and endoscopy scores, and higher number of sinonasal surgeries. ${ }^{3,32,33}$ Bilodeau et $\mathrm{al}^{34}$ showed that, among asthmatic subjects, those with CRSwNP presented more poorly controlled asthma, increased airway obstruction, and more marked lower airway inflammation than those without CRSwNP. The same authors have suggested that a subgroup of asthmatic patients may have a more intense lower airway inflammation in relation to the presence of CRSwNP. They observed that asthmatic subjects using intranasal corticosteroids (ICS) to treat nasal polyps had a more intense inflammation and a poorer asthma control compared to patients with chronic rhinosinusitis without nasal polyps, reflecting a more severe subset of asthma.

Asthma and CRSwNP have been also linked with an impaired quality of life (QoL); patients suffering from asthma and CRS reporting a poorer quality QoL. ${ }^{32}$ Alobid et $\mathrm{al}^{35}$ reported 109 patients with CRSwNP who were randomized to either receive oral prednisone for 2 weeks or to undergo endoscopic sinus surgery, all patients being treated with intranasal budesonide for 12 months. They observed a considerable impact of CRSwNP on patients' QoL, this being 
even worse in patients with concomitant asthma mainly on physical functioning, body pain, and vitality $(P<0.05)$. The same group ${ }^{10}$ evaluated different outcomes of patients with CRSwNP and found that asthma and especially persistent asthma have an accumulative impact on the loss of smell, proposing the loss of smell as a predictive symptom to identify severe asthma. Other authors have also found lower olfactory outcomes in patients who have associated CRSwNP and asthma ${ }^{36}$ or AERD. ${ }^{37}$

\section{Management challenges}

The European position paper on rhinosinusitis and nasal polyps provides a specific treatment guideline for patients with CRSwNP with and without asthma. ${ }^{1}$ On the basis of available evidence, medical therapy for CRSwNP should begin with daily application of a topical ICS in conjunction with high-volume saline irrigation, and subsequent therapies are based on the patient's polyp status, severity of symptoms, and/or QoL impairment. Regarding the question about how sinus surgery and medical CRSwNP treatment may modify the course of bronchial asthma, different authors ${ }^{38,39}$ have concluded that the weight of evidence suggests a beneficial effect. A recent systematic review ${ }^{40}$ analyzed the effect of upper airway intervention in the subpopulation of patients with coexisting CRSwNP and asthma and did not find marked differences between outcomes after endoscopic sinus surgery (ESS) or medical treatment with montelukast, omalizumab, or erythromycin.

\section{Medical treatments}

When analyzing the evidence of medical treatment specifically for patients with CRSwNP and coexisting asthma, there are a few randomized controlled trials and uncontrolled prospective interventional studies that evaluated the efficacy of different treatments. Alobid et $\mathrm{al}^{35}$ prospectively studied 109 patients with CRSwNP with and without asthma. They observed that patients with CRSwNP have a significantly worse QoL than the general population and that steroid treatment and ESS lead to similar QoL improvement in CRSwNP, either with or without asthma; both steroid and ESS treatments improve nasal symptoms in patients with CRSwNP. Two montelukast trials with follow-up times of 10 weeks and 13 weeks were done. Schäper et $\mathrm{al}^{41}$ investigated the effect of montelukast $(10 \mathrm{mg} / \mathrm{d})$ in a double-blinded, placebo-controlled crossover trial ( 6 weeks of intervention, 4 weeks of placebo) in 24 patients. Short acting $\beta$-agonists and baseline doses of inhaled steroids were allowed. Ragab et $\mathrm{al}^{42}$ studied 44 patients with montelukast $(10 \mathrm{mg} / \mathrm{d})$ treat- ment for 3 months as an add-on therapy to inhaled steroids and intranasal steroids (INCS) in an uncontrolled prospective trial. Significant improvements in nasal and pulmonary symptoms, results of endoscopy and CT scanning of the paranasal sinuses, and asthma medication intake were reported in both trials. Nevertheless, no significant improvements were found in nasal and pulmonary function test results; however, Schäper et $\mathrm{al}^{41}$ found montelukast to increase peak expiratory flow significantly $(P<0.05)$.

Immunoglobulin E (IgE) activates mast cells, and its levels are elevated in people with allergic diseases. ${ }^{1}$ The monoclonal antibody omalizumab lowers the level of $\operatorname{IgE}$ through selective binding, and anti-IgE is used in the treatment of uncontrolled allergic asthma. Omalizumab significantly improved nasal outcomes (symptoms, nasal endoscopy, and CT results) and QoL but did not significantly improve pulmonary outcomes (symptoms and pulmonary function test results). Gevaert et $\mathrm{al}^{43}$ studied 24 patients with and without allergy in a 16-week double-blinded, placebo-controlled trial. Omalizumab was given as an add-on to "standardized asthma treatment", and during the trial oral steroids and antibiotics were prohibited. They observed significant improvements in nasal symptoms, endoscopy results, and opacification on CT scans in the omalizumab group over those in the placebo group, irrespective of allergy status. Vague results in the omalizumab group were seen in relation to the lower airways; significant improvements were found in two of three pulmonary symptoms, but no significant changes were found in pulmonary function test results. The same group, ${ }^{44}$ in a randomized, double-blind, placebo-controlled trial of 30 patients with severe nasal polyposis, observed in 12 patients who received mepolizumab (two doses) radiographic and endoscopic improvement in nasal polyp burden compared to patients in the placebo arm, after 8 weeks of treatment. Although mepolizumab led to a reduction in loss of smell, postnasal drip, and nasal congestion, these results did not reach statistical significance, and the benefit in nasal symptoms normalized after a period of time, except for improvement in olfaction. Gevaert et $\mathrm{al}^{45}$ showed that a single injection of reslizumab, another anti-IL-5 monoclonal antibody, improved nasal polyp scores in $50 \%$ of patients with CRSwNP, and nasal IL-5 levels predicted the response to treatment. These studies support that a select population of patients with severe nasal polyposis may benefit from anti-IL-5 therapy, although, once again, larger studies are needed to corroborate these findings.

Finally, in addition to the known antimicrobial effects, long-term low-dose treatment with a macrolide such as 
erythromycin is believed to have immunomodulatory effects. Erythromycin improved nasal symptoms and was superior to ESS in improving pulmonary outcomes (symptoms and pulmonary function test results). ${ }^{40}$ Ragab et $\mathrm{al}^{46}$ randomized a heterogeneous group of chronic rhinosinusitis without nasal polyps and CRSwNP patients with asthma who failed initial medical therapy with INCS and nasal lavage to continued medical therapy or surgery. Patients randomized to continued medical therapy received erythromycin for 12 weeks, nasal lavage, and fluticasone drops, and some patients with CRSwNP received oral steroids. Both the medical and the surgery groups had improved asthma at 12-month follow-up; evermore the continued medical therapy group (erythromycin group) had greater improvement in objective pulmonary function tests. When analyzing treatments used in both CRSwNP and asthma, the most used treatments are leukotriene antagonists, monoclonal antibodies, and macrolide antibiotics.

\section{Surgical treatments}

The surgical treatment of nasal polyps by means of ESS leads to a subjective improvement of asthma symptoms and a decrease in hospital admissions, emergency department visits, asthma exacerbations, and the need of medication for disease control. There is also growing evidence supporting that aggressive surgical management of CRSwNP can consequently lead to a greater improvement of asthma severity. ${ }^{47-49}$ Palmer et al ${ }^{50}$ retrospectively re-evaluated the clinical histories of 15 subjects who had both CRS and steroid-dependent asthma, investigating the asthma relapse days and total dose of oral corticosteroid or antibiotics needed before and after ESS. They observed that $93 \%$ of patients significantly reduced their postoperative prednisone or antibiotic needs by total number of days. Senior et $\mathrm{al}^{51}$ reported that $90 \%$ of asthmatic patients $(n=30)$ who underwent ESS for CRS reduced the number of asthma exacerbations and need for medication after a follow-up period of 6.5 years. In the same line of research, Manning et $\mathrm{al}^{52}$ found that children with CRS and asthma $(n=14)$ who underwent ESS had a decreased number of asthma hospitalizations and missed schooldays. Other authors ${ }^{36,53}$ have observed that asthma patients undergoing ESS for CRSwNP had a significant improvement in pulmonary function and a reduction of systemic medication, respectively, but they failed to show improvement in AERD patients. Trials studying impact of CRSwNP treatment on asthma are summarized in Table 1. Recently, Leung et $\mathrm{al}^{54}$ simulated an evidence-based risk analysis using literature-reported complication rates, QoL changes, and Medicare costs to identify the threshold at which the risks of repeated courses of corticosteroid exceeded the risks of surgery. They found that the risks of oral corticosteroid exceed the risks of ESS when patients exceed 0.20 (CRSwNP), 0.53 (CRSwNP/asthma), or 1.81 (Samter's triad) courses of oral corticosteroids per year or need oral corticosteroid more frequently than every 5 years, 2 years, or 6 months, respectively. In ESS trials, all nasal outcomes (symptoms, nasal endoscopy, and pulmonary function test results) and QoL improved significantly although ambiguous results were reported for pulmonary outcomes (symptoms, pulmonary function test results, and asthma medication intake). A systematic review has found that ESS improves asthma control while decreasing asthma exacerbations, hospitalizations, and use of systemic and inhaled corticosteroids, pulmonary function being however unchanged. ${ }^{55}$ According to these findings, the current widespread belief is that comorbid asthmatic conditions of CRSwNP patients improve after ESS.

On the other hand, some authors have reported that asthma does not represent a predictor of poor symptomatic outcome after primary ${ }^{56,57}$ or revision ${ }^{58}$ ESS. Concomitant asthma was associated with worse postoperative endoscopic findings in two retrospective analyses, but had no significant weight on other objective outcomes. Symptoms improved significantly in both asthmatics and nonasthmatics postoperatively, but asthmatics exhibited worse postoperative endoscopic outcomes. ${ }^{59,60}$ In a series of 120 patients undergoing ESS, Kennedy ${ }^{26}$ reported that asthma did not affect the surgical outcomes when comparing patients with similar sinonasal disease severity, excluding the worst patients in whom asthma negatively affected the outcome. Seybt et $a l^{61}$ did not find differences in CRS patients with or without asthma in terms of the need for primary sinonasal surgery, but they observed that asthmatics had a significantly increased number of secondary surgeries. Uri et al ${ }^{62}$ reported that in patients with CRSwNP and asthma, ESS did not affect the asthma status. Lin et al, ${ }^{24}$ in a prospective trial including 224 CRS patients, could not confirm the beneficial effect of ESS on modifying the severity of asthma measured by objective lung function.

These findings suggest a benefit of early therapy for CRS in asthmatics if CRS is considered a reason for poor asthma control. Similarly, asthmatics with difficult-to-control illness should be assessed for unsuspected CRS, with CT scanning or nasal endoscopy, since CRS signs and symptoms may be 
Table I Trials evaluating the impact of CRS surgical treatment on asthma

\begin{tabular}{|c|c|c|c|c|c|}
\hline Study (year) & $\begin{array}{l}\text { LOE } \\
\text { (la to } 5)\end{array}$ & Study design & Study groups & Clinical endpoints & Conclusion \\
\hline \multirow[t]{2}{*}{$\begin{array}{l}\text { Swierczyńska-Krępa } \\
\text { et al }{ }^{65}\end{array}$} & lb & $\begin{array}{l}\text { Prospective } \\
\text { randomized trial }\end{array}$ & I. AIA patients with nasal polyps & $\begin{array}{l}\text { I. Nasal clinical and biochemical } \\
\text { parameters }\end{array}$ & $\begin{array}{l}\text { I. Only patients with AIA } \\
\text { had clinically beneficial } \\
\text { effects of AD on nasal } \\
\text { and bronchial symptoms }\end{array}$ \\
\hline & & & 2. ATA patients with nasal polyps & $\begin{array}{l}\text { 2. Lower airway clinical and } \\
\text { biochemical parameters }\end{array}$ & \\
\hline \multirow[t]{3}{*}{ Ehnhage et $\mathrm{a}^{36}$} & $\mathrm{lb}$ & $\begin{array}{l}\text { Prospective } \\
\text { randomized trial }\end{array}$ & CRSwNP and asthma, after FESS & I. Nasal symptoms improvement & $\begin{array}{l}\text { I. FESS improve nasal and } \\
\text { lower airway symptoms }\end{array}$ \\
\hline & & & Group I, FPND $400 \mu \mathrm{g}$ & 2. Polyp score & $\begin{array}{l}\text { 2. No significant differences } \\
\text { between FPND group } \\
\text { and placebo regarding } \\
\text { nasal and lower airway } \\
\text { symptoms }\end{array}$ \\
\hline & & & Group 2, placebo & $\begin{array}{l}\text { 3. Lower airway symptoms } \\
\text { improvement }\end{array}$ & $\begin{array}{l}\text { 3. Potential benefits of } \\
\text { FPND were probably } \\
\text { overshadowed by FESS }\end{array}$ \\
\hline \multirow[t]{4}{*}{ Ragab et a ${ }^{64}$} & $\mathrm{lb}$ & $\begin{array}{l}\text { Prospective } \\
\text { randomized trial }\end{array}$ & Surgical group, CRSsNP/CRSwNP & I. Asthma symptoms and control & $\begin{array}{l}\text { Improving symptoms in } \\
\text { medical group }\end{array}$ \\
\hline & & & & 2. $\mathrm{FEV}_{1}$ and peak flow & Improving FEV \\
\hline & & & Medical group, CRSsNP/CRSwNP & I. Medication use & Lowering medication needs \\
\hline & & & & 2. Hospitalization & $\begin{array}{l}\text { Lowering hospitalization } \\
\text { rate }\end{array}$ \\
\hline \multirow[t]{4}{*}{ Vashishta et al ${ }^{55}$} & $2 a$ & Systematic review & v I. CRS patients & I. Overall asthma control & $\begin{array}{l}\text { FESS in patients with } \\
\text { concomitant bronchial } \\
\text { asthma improves clinical } \\
\text { asthma outcome measures, } \\
\text { but not lung function } \\
\text { testing }\end{array}$ \\
\hline & & & & 2. Asthma attacks & \\
\hline & & & $\begin{array}{l}\text { 2. At least one asthma outcome } \\
\text { reported }\end{array}$ & I. Number of hospitalizations & \\
\hline & & & & 2. Use of oral corticosteroids & \\
\hline \multirow[t]{2}{*}{ Dejima et al ${ }^{66}$} & $2 a$ & $\begin{array}{l}\text { Prospective } \\
\text { controlled trial }\end{array}$ & I. CRS with asthma & I. Lower airway symptoms & Improving symptoms \\
\hline & & & 2. CRS without asthma & 2. Sinonasal symptoms & $\begin{array}{l}\text { Lowering medication needs } \\
\text { Improving FEV }\end{array}$ \\
\hline \multirow[t]{2}{*}{ Ikeda et al ${ }^{67}$} & $2 a$ & $\begin{array}{l}\text { Prospective } \\
\text { controlled }\end{array}$ & I. CRSWNP & $\begin{array}{l}\text { I. Sinonasal and pulmonary } \\
\text { symptoms }\end{array}$ & Improving FEV \\
\hline & & & 2. CRSsNP & 2. Medication use & $\begin{array}{l}\text { Any changes in medication } \\
\text { needs }\end{array}$ \\
\hline \multirow[t]{6}{*}{ Ehnhage et $\mathrm{al}^{68}$} & $2 b$ & Cohort study & $\begin{array}{l}\text { Patients with CRSwNP and asthma, } \\
\text { after FESS }\end{array}$ & I. Dyspnea/cough scores & $\begin{array}{l}\text { I. Improvement in asthma } \\
\text { symptoms score }\end{array}$ \\
\hline & & & & $\begin{array}{l}\text { 2. Mean daily peak expiratory } \\
\text { flow rate }\end{array}$ & \\
\hline & & & & 3. Spirometry & $\begin{array}{l}\text { 2. Improvement in daily } \\
\text { peak expiratory flow }\end{array}$ \\
\hline & & & & 4. Butanol test & \\
\hline & & & & 5. Olfaction score & \\
\hline & & & & $\begin{array}{l}\text { 6. Peak nasal inspiratory flow } \\
\text { 7. Polyps score }\end{array}$ & $\begin{array}{l}\text { 3. Improvement in all nasal } \\
\text { parameters }\end{array}$ \\
\hline \multirow[t]{3}{*}{ Uri et a ${ }^{62}$} & $2 b$ & $\begin{array}{l}\text { Prospective not } \\
\text { controlled }\end{array}$ & CRSwNP and asthma & $\begin{array}{l}\text { I. Subjective asthma and sinonasal } \\
\text { questionnaire }\end{array}$ & Improving symptoms \\
\hline & & & & 2. Spirometry & Lowering medication needs \\
\hline & & & & 3. Medication use & No changes in $\mathrm{FEV}_{\text {, }}$ \\
\hline
\end{tabular}


Table I (Continued)

\begin{tabular}{|c|c|c|c|c|c|}
\hline Study (year) & $\begin{array}{l}\text { LOE } \\
\text { (la to } 5)\end{array}$ & Study design & Study groups & Clinical endpoints & Conclusion \\
\hline \multirow[t]{2}{*}{ Lamblin et al ${ }^{69}$} & $2 b$ & $\begin{array}{l}\text { Prospective not } \\
\text { controlled }\end{array}$ & & I. Nasal symptoms & Any changes in symptoms \\
\hline & & & CRSwNP and asthma & $\begin{array}{l}\text { 2. Lower airway clinical and } \\
\text { biochemical parameters }\end{array}$ & $\begin{array}{l}\text { Any changes in asthma } \\
\text { severity } \\
\text { Any changes in } \\
\text { methacholine test }\end{array}$ \\
\hline \multirow[t]{3}{*}{ Senior et $\mathrm{al}^{51}$} & $2 b$ & $\begin{array}{l}\text { Prospective not } \\
\text { controlled }\end{array}$ & & I. Symptoms score & Improving symptoms \\
\hline & & & CRS with asthma & 2. Asthma exacerbations & Lowering asthma relapses \\
\hline & & & & 3. Medication use & Lowering medication needs \\
\hline Manning et $\mathrm{al}^{52}$ & $2 b$ & $\begin{array}{l}\text { Prospective not } \\
\text { controlled }\end{array}$ & & Symptoms score & Lowering medication need \\
\hline \multirow[t]{3}{*}{ Nishioka et al0 ${ }^{70}$} & $2 b$ & $\begin{array}{l}\text { Prospective not } \\
\text { controlled }\end{array}$ & & I. Symptoms score & Improving symptoms \\
\hline & & & Adults with CRS after FESS & 2. Medication use & Lowering medication needs \\
\hline & & & & 3. Number of emergency visits & Lowering emergency visits \\
\hline Zhang et $\mathrm{al}^{71}$ & 3 & Retrospective & Adults with CRS after FESS & QoL (SNOT-22) & $\begin{array}{l}\text { Patients with both asthma } \\
\text { and CRSwNP or asthma } \\
\text { alone experience a larger } \\
\text { QoL benefit after FESS } \\
\text { (I and } 3 \text { months) } \\
\text { compared to CRS patients } \\
\text { without asthma or polyps }\end{array}$ \\
\hline \multirow[t]{3}{*}{ Batra et $\mathrm{al}^{53}$} & 3 & Retrospective & CRSwNP and asthma & I. Symptoms score & Improving symptoms \\
\hline & & & & $\begin{array}{l}\text { 2. Medication use } \\
\text { 3. Number of emergency visits }\end{array}$ & $\begin{array}{l}\text { Lowering medication needs } \\
\text { Lowering number of } \\
\text { emergency visits }\end{array}$ \\
\hline & & & & 4. $\mathrm{FEV}$, change & Any changes in $\mathrm{FEV}_{\mathrm{1}}$ \\
\hline Palmer et al ${ }^{50}$ & 3 & Retrospective & Adults with CRS after FESS & $\begin{array}{l}\text { I. Lung function } \\
\text { 2. Medication use }\end{array}$ & Lowering medication needs \\
\hline \multirow[t]{4}{*}{ Dunlop et $\mathrm{al}^{72}$} & 3 & Retrospective & I. CRSWNP & I. Symptoms score & Improving symptoms \\
\hline & & & & 2. Medication use & Lowering medication needs \\
\hline & & & & 3. Number of emergency visits & $\begin{array}{l}\text { Lowering hospitalization } \\
\text { rates }\end{array}$ \\
\hline & & & 2. CRSsNP & 4. FEV, change & $\begin{array}{l}\text { Improving FEV } \\
\text { Any changes in CRSwNP } \\
\text { group }\end{array}$ \\
\hline \multirow[t]{5}{*}{ Goldstein et $\mathrm{al}^{73}$} & 3 & Retrospective & Adults with CRS after FESS & I. Any changes in symptoms & No improvement after ESS \\
\hline & & & & 2. Medication needs & \\
\hline & & & & 3. Hospitalization rate & \\
\hline & & & & 4. Emergency visits & \\
\hline & & & & 5. FEV , change & \\
\hline
\end{tabular}

Abbreviations: LOE, level of evidence; AIA, asthma intolerant to nonsteroidal antinflammatory drugs; ATA, asthma tolerant to nonsteroidal anti-inflammatory drugs; AD, aspirin desensitization; CRSsNP, chronic rhinosinusitis without nasal polyps; CRSwNP, chronic rhinosinusitis with nasal polyps; FESS, functional endoscopic sinus surgery; SNOT, sinonasal outcome test; QoL, quality of life; FPND; fluticasone propionate nasal drops; FEV $_{1}$, forced expiratory volume in I second.

subtle and overlooked if not specifically sought. We have highlighted that there exist only a few good quality studies of the treatment for CRSwNP with coexisting asthma, which underlines the need for further research in terms of both quality and quantity of the studies. The effect of ESS on pulmonary outcomes has been a question of great debate. We found low evidence to support a positive effect of both ESS and medical intervention on pulmonary function tests and asthma medication intake. Rix et $\mathrm{al}^{40}$ and Vashishta et $\mathrm{al}^{55}$ observed that patients who underwent ESS had an improvement in clinical asthma outcomes, but no significant change in pulmonary function test results. The effect of montelukast and other leukotriene antagonists on CRSwNP was evaluated in a recent systematic review and meta-analysis; ${ }^{63}$ improvements in symptoms and clinical outcomes were described by all 12 included studies after leukotriene antagonist treatment, 
but pulmonary function test results were sparse. Ragab et $\mathrm{al}^{64}$ published a randomized, prospective trial on patients with chronic rhinosinusitis without nasal polyps or CRSwNP and asthma comparing surgical versus medical treatment. They found that medical as well as surgical treatments for CRS showed improvements in asthma status with a good correlation to the improvement achieved in upper airway symptoms. Exhaled nitric oxide levels and forced expiratory volume in 1 second $\left(\mathrm{FEV}_{1}\right)$ improved in both groups with predominance in the medical treatment group of patients with CRSwNP.

\section{Conclusion}

Although there has been major advances in this field, there is still a lack of consistent evidence to reach firm conclusions about the relationship between upper and lower airway inflammatory diseases, their natural history, pathophysiology, and medical/surgical management. Research on the basic pathophysiology of the nose and demonstration of the unified airway concept are mandatory. Clarification is also required concerning whether CRS management affects other comorbid lower airway diseases such as asthma, chronic obstructive respiratory disease, and bronchiectasis. Randomized clinical trials with a good level of scientific evidence need to be performed to better understand the available treatments for comorbid upper and lower inflammatory diseases.

\section{Disclosure}

The authors report no conflicts of interest in this work.

\section{References}

1. Fokkens WJ, Lund VJ, Mullol J, et al. European position paper on rhinosinusitis and nasal polyps 2012. Rhinology. 2012;23:1-298.

2. Bousquet J. Global initiative for asthma (GINA) and its objectives. Clin Exp Allergy. 2000;(Suppl 1):2-5.

3. Pearlman AN, Chandra RK, Chang D, et al. Relationships between severity of chronic rhinosinusitis and nasal polyposis, asthma, and atopy. $\mathrm{Am}$ J Rhinol Allergy. 2009;23:145-148.

4. Bousquet J, Khaltaev N, Cruz A, et al. Allergic Rhinitis and its Impact on Asthma (ARIA) 2008 update (in collaboration with the World Health Organization, GA(2)LEN and AllerGen). Allergy. 2008;63 (Suppl 86):8-160.

5. Gaga M, Lambrou P, Papageorgiou N, et al. Eosinophils are a feature of upper and lower airway pathology in non-atopic asthma, irrespective of the presence of rhinitis. Clin Exp Allergy. 2000;30:663-669.

6. Braunstahl GJ, Kleinjan A, Overbeek SE, Prins JB, Hoogsteden HC, Fokkens WJ. Segmental bronchial provocation induces nasal inflammation in allergic rhinitis patients. Am J Respir Crit Care Med. 2000;161:2051-2057.

7. Ponikau JU, Sherris DA, Kephart GM, et al. Features of airway remodeling and eosinophilic inflammation in chronic rhinosinusitis: is the histopathology similar to asthma? $J$ Allergy Clin Immunol. $2003 ; 112: 877-882$.
8. Bachert C, Nan Z, Gabriele H, et al. Presence of IL-5 protein and IgE-antibodies to staphylococcal enterotoxins in nasal polyps is associated with co-morbid asthma. J Allergy Clin Immunol. 2010;126: 962-968.

9. Jarvis D, Newson R, Lotvall J, et al. Asthma in adults and its association with chronic rhinosinusitis: the GA2LEN survey in Europe. Allergy. 2012;67:91-98.

10. Alobid I, Cardelus S, Benítez P, et al. Persistent asthma has an accumulative impact on the loss of smell in patients with nasal polyposis. Rhinology. 2011;49:519-524.

11. Szczeklik A, Nizankowska E, Duplaga M. Natural history of aspirininduced asthma. AIANE Investigators. European Network on AspirinInduced Asthma. Eur Respir J. 2000;16:432-436.

12. Mullol J, Picado C. Rhinosinusitis and nasal polyps in aspirinexacerbated respiratory disease. Immunol Allergy Clin North Am. 2013;33:163-176.

13. Guilemany JM, Angrill J, Alobid I, et al. United airways: the impact of chronic rhinosinusitis and nasal polyps in bronchiectasic patient's quality of life. Allergy. 2009;64:1524-1529

14. Larsen K. The clinical relationship of nasal polyps to asthma. Allergy Asthma Proc. 1996;17:243-249.

15. Zhang N, Van Zele T, Perez-Novo C, et al. Different types of T-effector cells orchestrate mucosal inflammation in chronic sinus disease. J Allergy Clin Immunol. 2008;122:961-968.

16. Klossek JM, Neukirch F, Pribil C, et al. Prevalence of nasal polyposis in France: a cross-sectional, case-control study. Allergy. 2006;60:233-237.

17. Mullol J, Guilemany JM, Alobid I. Relación de la rinitis y la rinosinusitis con la gravedad del asma. Rev Rinol. 2011;11:23-27.

18. Thorstensen WM, Bugten V, Sue-Chu M, Fossland NPW, Romundstad PR, Steinsvåg SK. Sino-nasal characteristics in asthmatic patients. Otolaryngol Head Neck Surg. 2012;147:950-957.

19. Dixon AE, Kaminsky DA, Holbrook JT, Wise RA, Shade DM, Irvin CG. Allergic rhinitis and sinusitis in asthma: differential effects on symptoms and pulmonary function. Chest. 2006;130:429-435.

20. Bousquet J, Schünemann HJ, Samolinski B; World Health Organization Collaborating Center for Asthma and Rhinitis. Allergic Rhinitis and its Impact on Asthma (ARIA): achievements in 10 years and future needs. J Allergy Clin Immunol. 2012;130:1049-1062.

21. Settipane GA, Chafee FH. Nasal polyps in asthma and rhinitis. A review of 6,037 patients. J Allergy Clin Immunol. 1977;59:17-21.

22. Bachert C, Claeys SEM, Tomassen P, van Zele T, Zhang N. Rhinosinusitis and asthma: a link for asthma severity. Curr Allergy Asthma Rep. 2010;10:194-201.

23. Bachert $\mathrm{C}$, Zhang N. Chronic rhinosinusitis and asthma: novel understanding of the role of IgE "above atopy." J Intern Med. 2012;272:133-143.

24. Lin DC, Chandra RK, Tan BK, et al. Association between severity of asthma and degree of chronic rhinosinusitis. Am J Rhinol Allergy. 2011;25:205-208.

25. Zhang Z, Linkin DR, Finkelman BS, et al. Asthma and biofilm forming bacteria are independently associated with revision sinus surgeries for chronic rhinosinusitis. J Allergy Clin Immunol. 2011;128:221-223.

26. Kennedy DW. Prognostic factors, outcomes and staging in ethmoid sinus surgery. Laryngoscope. 1992;102(Suppl 57):1-18.

27. Mariño FS, Alobid I, Guilemany JM, Mullol J, Obando A. Tratamiento médico y quirúrgico de la poliposis nasal. Efecto sobre el asma. Rev Rinol. 2009;9:26-32.

28. Hedman J, Kaprio J, Poussa T, Nieminen M. Prevalence of asthma, aspirin intolerance, nasal polyposis and chronic obstructive pulmonary disease in a population-based study. Int J Epidemiol. 1999;4:717-722.

29. Ragab A, Clement P, Vincken W. Objective assessment of lower airway involvement in chronic rhinosinusitis. Am J Rhinol. 2004;18:15-21.

30. Szczeklik A, Stevenson DD. Aspirin-induced asthma: advances in pathogenesis, diagnosis, and management. J Allergy Clin Immunol. 2003;111:913-921. 
31. Berges-Gimeno MP, Simon RA, Stevenson DD. The natural history and clinical characteristics of aspirin-exacerbated respiratory disease. Ann Allergy Asthma Immunol. 2002;89:474-478.

32. Lehrer E, Mullol J, Agredo F, Alobid I. Management of chronic rhinosinusitis in asthma patients: is there still a debate? Curr Allergy Asthma Rep. 2014;14:440.

33. Staikūniene J, Vaitkus S, Japertiene LM, Ryskiene S. Association of chronic rhinosinusitis with nasal polyps and asthma: clinical and radiological features, allergy and inflammation markers. Med (Kaunas). 2008;44:257-265.

34. Bilodeau L, Boulay ME, Prince P, Boisvert P, Boulet LP. Comparative clinical and airway inflammatory features of asthmatics with or without polyps. Rhinology. 2010;48:420-425.

35. Alobid I, Benítez P, Bernal-Sprekelsen M, et al. Nasal polyposis and its impact on quality of life: comparison between the effects of medical and surgical treatments. Allergy. 2005;60:452-458.

36. Ehnhage A, Olsson P, Kölbeck K-G, et al. Functional endoscopic sinus surgery improved asthma symptoms as well as PEFR and olfactionin patients with nasal polyposis. Allergy. 2009;64:762-769.

37. Alobid I, Benítez P, Cardelús S, et al. Oral plus nasal corticosteroids improve smell, nasal congestion, and inflammation in sino-nasal polyposis. Laryngoscope. 2014;124:50-56.

38. Lund VJ. The effect of sinonasal surgery on asthma. Allergy. 1999; 54(Suppl 57):141-145.

39. Scadding G. The effect of medical treatment of sinusitis upon concomitant asthma. Allergy. 1999;54(Suppl 57):136-140.

40. Rix I, Håkansson K, Larsen CG, Frendø M, von Buchwald C. Management of chronic rhinosinusitis with nasal polyps and coexisting asthma: a systematic review. Am J Rhinol Allergy. 2015;29:193-201.

41. Schäper C, Noga O, Koch B, et al. Anti-inflammatory properties of montelukast, a leukotriene receptor antagonist in patients with asthma and nasal polyposis. J Investig Allergol Clin Immunol. 2011;21:51-58.

42. Ragab S, Parikh A, Darby YC, Scadding GK. An open audit of montelukast, a leukotriene receptor antagonist, in nasal polyposis associated with asthma. Clin Exp Allergy. 2001;31:1385-1391.

43. Gevaert P, Calus L, Van Zele T, et al. Omalizumab is effective in allergic and nonallergic patients with nasal polyps and asthma. J Allergy Clin Immunol. 2013;131:110-116.

44. Gevaert P, Van Bruaene N, Cattaert T, et al. Mepolizumab, a humanized anti-IL-5 mAb, as a treatment option for severe nasal polyposis. J Allergy Clin Immunol. 2011;128:989-995.

45. Gevaert P, Lang-Loidolt D, Lackner A, et al. Nasal IL-5 levels determine the response to anti-IL-5 treatment in patients with nasal polyps. J Allergy Clin Immunol. 2006;118:1133-1141.

46. Ragab SM, Lund VJ, Scadding G. Evaluation of the medical and surgical treatment of chronic rhinosinusitis: a prospective, randomised, controlled trial. Laryngoscope. 2004;114:923-930.

47. DeMarcantonio MA, Han JK. Nasal polyps: pathogenesis and treatment implications. Otolaryngol Clin North Am. 2011;44:685-695.

48. Ebbens FA, Toppila-Salmi SK, Renkonen JA, et al. Endothelial L-selectin ligand expression in nasal polyps. Allergy. 2010;65: 95-102.

49. van Drunen CM, Reinartz S, Wigman J, Fokkens WJ. Inflammation in chronic rhinosinusitis and nasal polyposis. Immunol Allergy Clin North Am. 2009;29:621-629.

50. Palmer JN, Conley DB, Dong RG, Ditto AM, Yarnold PR, Kern RC. Efficacy of endoscopic sinus surgery in the management of patients with asthma and chronic sinusitis. Am J Rhinol. 2001;15:49-53.

51. Senior BA, Kennedy DW, Tanabodee J, Kroger H, Hassab M, Lanza DC. Long-term impact of functional endoscopic sinus surgery on asthma. Otolaryngol Head Neck Surg. 1999;121:66-68.

52. Manning SC, Wasserman RL, Silver R, Phillips DL. Results of endoscopic sinus surgery in pediatric patients with chronic sinusitis and asthma. Arch Otolaryngol Head Neck Surg. 1994;120:1142-1145.
53. Batra PS, Kern RC, Tripathi A, et al. Outcome analysis of endoscopic sinus surgery in patients with nasal polyps and asthma. Laryngoscope. 2003;113:1703-1706

54. Leung RM, Dinnie K, Smith TL. When do the risks of repeated courses of corticosteroids exceed the risks of surgery? Int Forum Allergy Rhinol. 2014;4:871-876.

55. Vashishta R, Soler ZM, Nguyen SA, et al. A systematic review and meta-analysis of asthma outcomes following endoscopic sinus surgery for chronic rhinosinusitis. Int Forum Allergy Rhinol. 2013;3: 788-794.

56. Mehanna H, Mills J, Kelly B, McGarry GW. Benefit from endoscopic sinus surgery. Clin Otolaryngol Allied Sci. 2002;27:464-471.

57. Chambers DW, Davis WE, Cook PR, Nishioka GJ, Rudman DT. Longterm outcome analysis of functional endoscopic sinus surgery: correlation of symptoms with endoscopic examination findings and potential prognostic variables. Laryngoscope. 1997;107:504-510.

58. Kountakis SE, Bradley DT. Effect of asthma on sinus computed tomography grade and symptom scores in patients undergoing revision functional endoscopic sinus surgery. Am J Rhinol. 2006;17:215-219.

59. Smith TL, Mendolia-Loffredo S, Loehrl TA, Sparapani R, Laud PW, Nattinger AB. Predictive factors and outcomes in endoscopic sinus surgery for chronic rhinosinusitis. Laryngoscope. 2005; 115:2199-2205.

60. Marks SC, Shamsa F. Evaluation of prognostic factors in endoscopic sinus surgery. Am J Rhinol. 1997;11:187-191.

61. Seybt MW, McMains KC, Kountakis SE. The prevalence and effect of asthma on adults with chronic rhinosinusitis. Ear Nose Throat J. 2007;86:409-411.

62. Uri N, Cohen-Kerem R, Barzilai G, Greenberg E, Doweck I, Weiler-Ravell D. Functional endoscopic sinus surgery in the treatment of massive polyposis in asthmatic patients. J Laryngol Otol. 2002;116:185-189.

63. Wentzel JL, Soler ZM, DeYoung K, et al. Leukotriene antagonists in nasal polyposis: a meta-analysis and systematic review. Am J Rhinol Allergy. 2013;27:482-489.

64. Ragab S, Scadding GK, Lund VJ, et al. Treatment of chronic rhinosinusitis and its effects on asthma. Eur Respir J. 2006;28:68-74.

65. Swierczyńska-Krępa M, Sanak M, Bochenek G, et al. Aspirin desensitization in patients with aspirin-induced and aspirin-tolerant asthma: a double-blind study. JACI. 2014;134:883-890.

66. Dejima K, Hama T, Miyazaki M, et al. A clinical study of endoscopic sinus surgery for sinusitis in patients with bronchial asthma. Int Arch Allergy Immunol. 2005;138:97-104.

67. Ikeda K, Tanno N, Tamura G, et al. Endoscopic sinus surgery improves pulmonary function in patients with asthma associated with chronic sinusitis. Ann Otol Rhinol Laryngol. 1999;108:355-359.

68. Ehnhage A, Olsson P, Kölbeck KG, Skedinger M, Stjärne P; NAFS Study Group. One year after endoscopic sinus surgery in polyposis: asthma, olfaction, and quality-of-life outcomes. Otolaryngol Head Neck Surg. 2012;146:834-841.

69. Lamblin C, Brichet A, Perez T, Darras J, Tonnel AB, Wallaert B. Longterm follow-up of pulmonary function in patients with nasal polyposis. Am J Respir Crit Care Med. 2000;161:406-413.

70. Nishioka GJ, Cook PR, Davis WE, McKinsey JP. Functional endoscopic sinus surgery in patients with chronic sinusitis and asthma. Otolaryngol Head Neck Surg. 1994;110:494-500.

71. Zhang Z, Adappa ND, Doghramji LJ, et al. Quality of life improvement from sinus surgery in chronic rhinosinusitis patients with asthma and nasal polyps. Int Forum Allergy Rhinol. 2014;4:885-892.

72. Dunlop G, Scadding GK, Lund VJ. The effect of endoscopic sinus surgery on asthma: management of patients with chronic rhinosinusitis, nasal polyposis, and asthma. Am J Rhinol. 1999;13:261-265.

73. Goldstein MF, Grundfast SK, Dunsky EH, Dvorin DJ, Lesser R. Effect of functional endoscopic sinus surgery on bronchial asthma outcomes. Arch Otolaryngol Head Neck Surg. 1999;125:314-319. 
Journal of Asthma and Allergy

\section{Publish your work in this journal}

The Journal of Asthma and Allergy is an international, peer-reviewed open-access journal publishing original research, reports, editorials and commentaries on the following topics: Asthma; Pulmonary physiology; Asthma related clinical health; Clinical immunology and the immunological basis of disease; Pharmacological interventions and

new therapies. Issues of patient safety and quality of care will also be considered. The manuscript management system is completely online and includes a very quick and fair peer-review system, which is all easy to use. Visit http://www.dovepress.com/testimonials.php to read real quotes from published authors.

Submit your manuscript here: http://www.dovepress.com/journal-of-asthma-and-allergy-journal 